\section{Fruit Weight, Cropload, and Return Bloom of 'Empire' Apple Following Thinning with 6-Benzyladenine and NAA at Several Phenological Stages}

\author{
Ed Stover ${ }^{1}$, Mike Fargione, and Richard Risio \\ Department of Horticultural Sciences, New York State Agricultural Experiment \\ Station, Cornell University, Hudson Valley Laboratory, Highland, NY 12528 \\ Xiaoe Yang \\ University of Florida, Indian River Research and Education Center, Ft. \\ Pierce, FL 34945-3138
}

\section{Terence Robinson \\ Department of Horticultural Sciences, New York State Agricultural Experiment Station, Cornell University, Geneva, NY 14456}

Additional index words. Accel ${ }^{\circledR}$, naphthaleneacetic acid, BA, carbaryl, Sevin ${ }^{\circledR}$, flowering, Malus $\times$ domestica, fruit size

\begin{abstract}
Thinning with BA reportedly increases size of 'Empire' fruit more than does thinning with NAA because of enhancement of cell division by BA. This study was conducted to determine the phenological stage at which $B A$ application provides maximum fruit weight relative to degree of cropload reduction. In all years, treatments were applied at a range of timings: petal fall (PF), 5-, 10-, or 15-mm king fruitlet diameter (KFD). For each thinner, the same concentration was used throughout the study. In 1994, only Accel ${ }^{\circledR}$ at $75 \mathrm{mg} \cdot \mathrm{L}^{-1}$ was evaluated. In 1995 , NAA $\left(7.5 \mathrm{mg} \cdot \mathrm{L}^{-1}\right)+\operatorname{carbaryl}(600$ $\mathrm{mg} \cdot \mathrm{L}^{-1}$ ), Accel $^{\circledR}$, and a BA-only formulation were compared, but $\mathrm{BA}$ alone was applied only at PF, 10- and 15-mm KFD. In 1996, Accel $^{\circledR}$ and NAA were compared with and without carbaryl at all timings. Most treatments reduced cropload and enhanced fruit weight. When data for all 3 years were combined, Accel ${ }^{\circledR}$ or BA increased croploadadjusted fruit weight (CAFW) in 8 of 10 treatments made at 10- or 15-mm KFD, PF treatments never increased CAFW, and only one of four applications at 5-mm KFD increased CAFW. In contrast, NAA + carbaryl increased CAFW in four of four treatments applied at PF or 5-mm KFD, but in only one of four treatments at 10- or 15mm KFD. Accel ${ }^{\circledR}$ was less effective than NAA in reducing fruit clusters to a single fruit per spur in most comparisons, either with or without carbaryl. Return bloom varied greatly across years, but was always influenced by application time and types of thinners. In 1994 and 1996, return bloom was closely related to cropload the previous year. Although return bloom was very low for most treatments in 1995, 10- and 15-mm KFD applications of NAA + carbaryl increased it three-fold in comparison with other treatments (NAA + carbaryl at PF or $5 \mathrm{~mm}$ or BA at 10-mm KFD) that had similar effects on cropload. Chemical names used: 6-benzyladenine (BA); naphthaleneacetic acid (NAA).
\end{abstract}

Chemical thinning, using materials that increase early fruitlet abscission and thus reduce number of fruit per tree, is a critical management practice influencing the profitability of commercial apple orchards. Reducing cropload with thinners typically reduces

Received for publication 24 May 2000. Accepted for publication 27 Dec. 2000. We are grateful to Ramon Littell, statistician at the Univ. of Florida, for assistance with statistical methods for assessing effects of treatments on fruit weight adjusted for cropload. The cost of publishing this paper was defrayed in part by the payment of page charges. Under postal regulations, this paper therefore must be hereby marked advertisement solely to indicate this fact.

${ }^{1}$ Current address: Univ. of Florida, Indian River Research and Education Center, 2199 South Rock Rd., Ft. Pierce, FL 34945-3138. E-mail address: ews@gnv.ifas.ufl.edu

total yield but increases production of larger high-value fruit and reduces biennial bearing and attendant production fluctuations (Forshey, 1986). Economic returns resulting from different chemical thinning methods may vary by more than $\$ 2500$ per ha (Stover, 1996), providing considerable incentive for optimizing cropload.

Most commercial apple producers in New York thin primarily with NAA alone or NAA + carbaryl, but fruit weight increase is often modest in some cultivars following cropload reduction. BA is an effective thinner and often appears to provide larger fruit for the same degree of thinning (Greene et al., 1992; Wismer et al., 1995). The commercial product Accel $^{\circledR}$ (Valent BioSciences Corp., Libertyville, Ill.) is labeled for chemical thinning of apple and has BA as its primary active ingredient, along with small amounts of gib- berellins $A_{4}$ and $A_{7}\left(\mathrm{GA}_{4+7}\right)$. Early commercial efforts to thin 'Empire' apple with Accel $^{\circledR}$ produced highly variable results, compromising grower acceptance. This project was initiated to determine: 1) the phenological stage when Accel $^{\circledR}$ produces maximum fruit weight enhancement; and 2) whether fruit weight increase and thinning can be manipulated independently, to permit reliable cropload reduction and larger fruit size relative to cropload.

\section{Materials and Methods}

Treatments. Trials were conducted from 1994-96 in commercial orchards in eastern New York State. Orchard blocks with productive and uniform 15-16-year-old trees were selected. Number of blossom clusters was counted on three branches with typical flowering and 5-8-cm basal diameter on each tree (1994) or on entire trees (1995-96). Trunk circumference was measured at $25 \mathrm{~cm}$ above the soil level, and where branch counts were employed, the circumference of branches used was also determined. Trees were blocked by number of blossom clusters per $\mathrm{cm}^{2}$ trunk cross-sectional area (TCSA) or per $\mathrm{cm}^{2}$ branch cross-sectional area (BCSA). Each treatment within an experiment was applied to seven or eight individual trees, with equal numbers of replications within years. Thinners were applied on a day near the indicated phenological stage with conditions considered best for chemical thinning (high temperature expected to reach 21 to $24^{\circ} \mathrm{C}$, temperature at application of 18 to $21^{\circ} \mathrm{C}$, slow drying conditions, and no rain expected for at least $6 \mathrm{~h}$ ). On a few dates, maximum temperatures exceeded the ideal range (Fig. 1). Almost all applications were made in the early morning when there was no dew on the trees. Chemical thinners were applied using a high-pressure handgun to runoff. BA was mainly used in the commercial product $\operatorname{Accel}^{\circledR}\left(10\right.$ parts BA to 1 part $\left.\mathrm{GA}_{4+7}\right)$, but a BA-only formulation was also tested in 1995. The formulation of NAA used was Fruitone-N, (Na salt) or Fruit Fix K-Salt 200, (K salt) (AmVac Chemicals, Newport Beach, Calif.). Carbaryl was used as Sevin ${ }^{\circledR}$ XLR+, (Rhone-Poulenc, Research Triangle Park, N.C.).
In 1994, Accel $^{\circledast}\left(75 \mathrm{mg} \cdot \mathrm{L}^{-1}\right.$ of BA, which is the maximum label rate) was applied to 15 year-old 'Empire' trees on M.9/MM.111 rootstock in Highland, N.Y. Applications were made at full bloom (FB), PF, and at 5-, 10-, and 15-mm king fruitlet diameter (KFD). In 1995 and 1996, treatments were applied to a block of 'Empire' trees on M.9/MM.111 rootstocks planted in 1981 at Clintondale, N.Y. In 1995, the same rate was used at PF, 5-, 10-, and 15-mm KFD and compared with NAA $\left(7.5 \mathrm{mg} \cdot \mathrm{L}^{-1}\right)$ plus carbaryl $\left(600 \mathrm{mg} \cdot \mathrm{L}^{-1}\right)$. A BA-only formulation was also compared at PF, 10- and 15-mm KFD. In 1996, Accel ${ }^{\circledR}$ (75 $\mathrm{mg} \cdot \mathrm{L}^{-1}$ BA) and NAA $\left(7.5 \mathrm{mg} \cdot \mathrm{L}^{-1}\right)$ were compared with and without carbaryl at 600 $\mathrm{mg} \cdot \mathrm{L}^{-1}$ at PF, 5-, 10-, and 15-mm KFD.

Data recorded. In 1995 and 1996, numbers of fruit per spur were recorded prior to harvest 

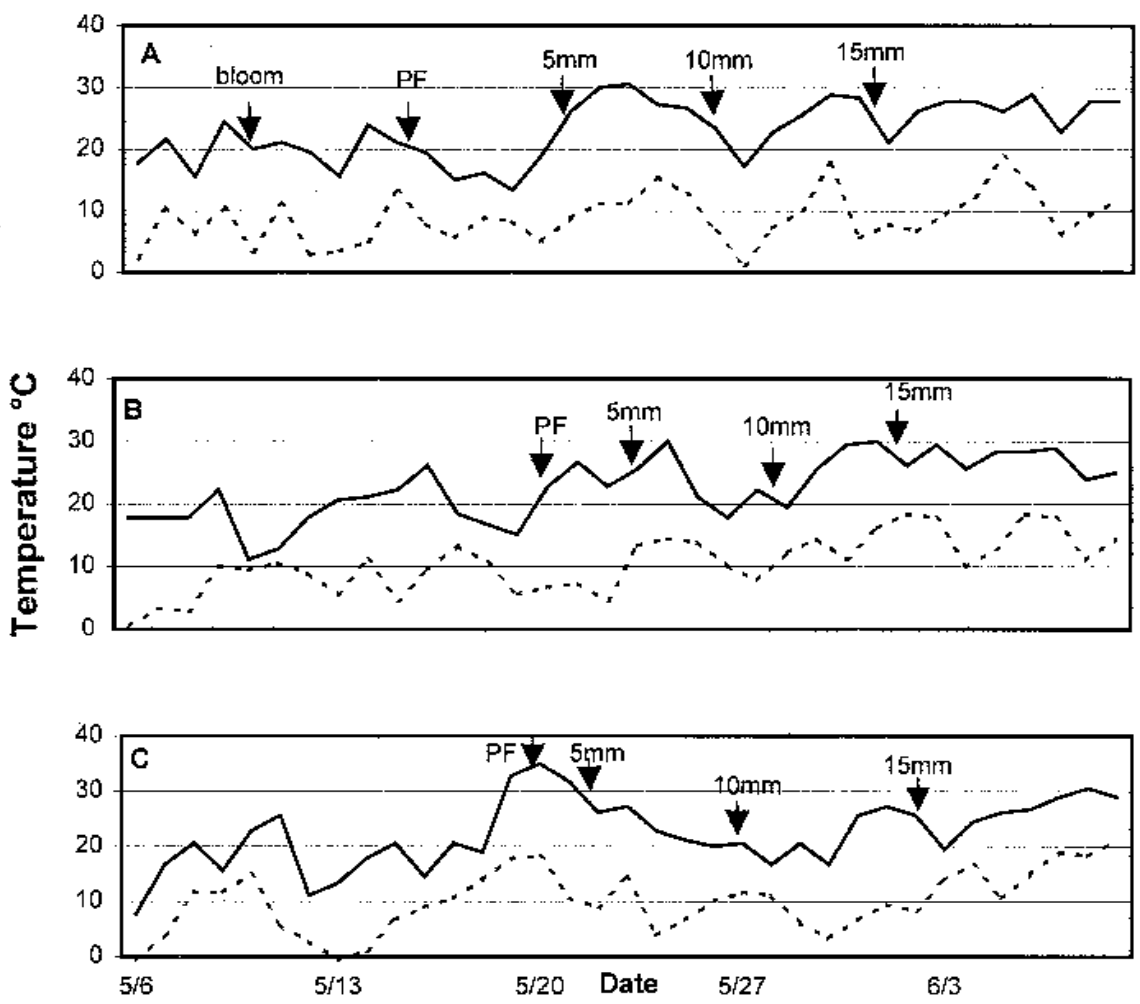

Fig. 1. Maximum (solid line) and minimum (dashed line) daily temperatures registered at nearby weather station (Hudson Valley Laboratory, Highland, N.Y.) during thinning period in (A) 1994, (B) 1995, and (C) 1996. Arrows indicate time of thinner application for each phenological stage in each year. Bloom $=80 \%$ of flowers open; $\mathrm{PF}=$ petal fall, indicating the time when virtually all petals have just dropped; all other phenological designations indicate mean king fruit diameter at time of application.

on 100-150 spurs per tree, on branches that appeared typical for cropload and branch diameter for each tree. At commercial harvest, all of the fruit were harvested, weighed, and counted. Numbers of drops were counted and assumed to be of average fruit weight. From these data, the mean fruit weight and number of fruit $/ \mathrm{cm}^{2}$ TCSA were determined for each tree. A random sample of 20 to 25 fruit was also collected from each tree every year for evaluation of weight, length, diameter, and seed number; the percentage of fruit surface with red color was also assessed in 1995. The spring following each year of treatment, flowering was recorded for 150 spurs on each tree, selecting branches of typical diameter and level of flowering on each tree.

CAFW was calculated for each tree, using the GLM procedure (SAS Institute, Cary, N.C.), by regressing mean fruit weight on cropload for all trees each year, generating the residual value for variation of each tree from the pooled correlation, and adding the residual to the overall mean fruit weight for the experiment. This was conducted prior to assessment of any block effect, and reflects, for each tree, the overall deviation in fruit weight from the experimental mean slope of fruit weight vs. cropload, including any direct effects of chemical thinners. All data including CAFW were subjected to analysis of variance (ANOVA) using the GLM procedure for a randomized complete-block design and means were separated using Waller-Duncan LSD at $P$ $\leq 0.05$. was applied at $\mathrm{PF}$ to $10-\mathrm{mm}$, and $\mathrm{Accel}^{\circledR}$ or $\mathrm{BA}$ applied at 10- to 15-mm KFD (Table 2). The percentage of spurs bearing a single fruit was increased by NAA + carbaryl at all application timings, by Accel $^{\circledR}$ at 10 - to $15-\mathrm{mm}$ KFD, and by BA only at $15-\mathrm{mm}$ KFD.

NAA + carbaryl increased the percentage of fruit surface with red color (except at PF), whereas Accel ${ }^{\circledR}$ and BA did not. Accel ${ }^{\circledR}$ at $15-$ $\mathrm{mm}$ KFD again reduced seed number (Table 2 ), but no treatment affected L/D ratio (data not shown).

The increase in return bloom following application of NAA + carbaryl differed greatly with application time. Only $7 \%$ of spurs on control trees produced flowers in the spring following treatment. Return bloom increased to $18 \%$ to $20 \%$ when the NAA + carbaryl was applied at $\mathrm{PF}$ and $5 \mathrm{~mm}$, and reached $56 \%$ to $62 \%$ when applied at 15 and $10 \mathrm{~mm}$, respectively (Table 2). Accel ${ }^{\circledR}$ had no effect on return bloom regardless of timing, and $\mathrm{BA}$ alone increased return bloom only at 10-mm KFD (Table 2).

1996. The cropload on nonthinned control trees was relatively low (9.0 fruit $/ \mathrm{cm}^{2}$ TCSA) and fruit were large (151 g/fruit) in 1996 . Nevertheless, the application of NAA at 5-mm $\mathrm{KFD}, \mathrm{NAA}+$ carbaryl at 5- to 15-mm KFD, Accel $^{\circledR}$ at $10-\mathrm{mm} \mathrm{KFD}$, or Accel ${ }^{\circledR}+$ carbaryl at 10 - to $15-\mathrm{mm}$ KFD significantly reduced cropload (Table 3). Fruit weight was increased by NAA applied at $15-\mathrm{mm}$ KFD, NAA + carbaryl at all four phenological stages, Accel ${ }^{\circledR}$ at $15-\mathrm{mm}$, and Accel $^{\circledR}+$ carbaryl at 5- to 15mm KFD (Table 3). Accel ${ }^{\circledR}$ applied at 15-mm, Accel $^{\circledR}+$ carbaryl applied at 5- to $15-\mathrm{mm}$ $\mathrm{KFD}$, and NAA + carbaryl at PF to 5-mm KFD all increased CAFW (Table 3). Even when cropload was not reduced, the percentage of spurs bearing single fruit was increased markedly by NAA, NAA + carbaryl, and Accel $^{\circledR}+$ carbaryl, whereas Accel ${ }^{\circledR}$ alone was only effective when applied at 10-mm KFD. NAA + carbaryl was more effective than Accel $^{\circledR}+$ carbaryl in increasing the percentage of spurs with one fruit at each application timing.

Application of Accel $^{\circledR}$ at 15 -mm and Accel ${ }^{\circledR}$ + carbaryl at 10- and 15-mm KFD reduced the seed number per fruit (3.4-3.7 vs. 4.6 for nonthinned trees), but NAA or NAA + carbaryl did not (4.0-5.1 seeds). The L/D ratio was increased by all Accel $^{\circledR}+$ carbaryl treatments, Accel $^{\circledR}$ at PF and 10-mm, NAA at 10$\mathrm{mm}$, and NAA + carbaryl at 15-mm (ratio was 0.85 for controls vs. 0.89 to 0.90 for significant treatments). Return bloom was very high for all treatments, as well as the nonthinned control, but was significantly increased by NAA at 10-mm KFD, NAA + carbaryl applied from 5- to 15-mm KFD, and Accel ${ }^{\circledR}+$ carbaryl applied at 10- to 15-mm KFD (Table 3).

\section{Discussion}

Consistent enhancement of fruit weight while maintaining high yields and good return bloom are the most important considerations in evaluating a chemical thinning program. Other considerations include red color development, percentage of spurs carrying only one 
fruit (which contributes to good color development and size), seed number per fruit (low numbers may compromise storage quality), and fruit shape (elongated fruit may be judged atypical for some cultivars and be less marketable). Marked reduction in cropping can result in large fruit weight but may reduce profitability. There are two major influences of chemical thinners on fruit weight; one is the reduction in cropload that indirectly affects fruit weight by reducing inter-fruit competition, and the other is the direct effect of the thinners on fruit growth (Forshey, 1990; Greene et al., 1990; Westwood, 1967; Wismer et al., 1995). For this reason, we evaluated cropload adjusted fruit weight (CAFW) as an indication of weight enhancement beyond the indirect effect due to reduced competition from thinning. The CAFW analysis used represents the best method we have identified for assessment of treatment effects on fruit size after removal of cropload influence. This method is not a typical covariate analysis and results in acceptably minimal violation of statistical assumptions (Ramon Littell, personal communication). A publication comparing this method to standard covariate analysis is in preparation.

In 2 of the 3 years of this study, application of Accel $^{\circledR}\left(75 \mathrm{mg} \cdot \mathrm{L}^{-1} \mathrm{BA}\right)$ at 10 - to $15-\mathrm{mm}$ KFD provided good fruit weight increases, an increase in CAFW, and sufficient cropload reduction to anticipate good return bloom. The enhancement of fruit growth by BA applica- tion was previously reported (Elfving and Cline, 1993; Greene et al., 1992), and has been attributed to increased cell division (Greene et al., 1990; Wismer et al., 1995). However, in 1995 and 1996, treatments with Accel ${ }^{\circledR}$ or BA before 10-mm KFD had little or no effect on cropload or fruit weight (Tables 2 and 3); in no case did $\mathrm{Accel}^{\circledR}$ or BA alone increase the CAFW when applied before 10-mm KFD. In only one instance did Accel $^{\circledR}$, Accel ${ }^{\circledR}+$ carbaryl, or BA significantly increase CAFW without also significantly reducing cropload; this was when Accel $^{\circledR}$ was applied at $15-\mathrm{mm}$ KFD in 1996 (Table 3). These data suggest that increases in fruit weight adjusted for cropload (CAFW) are most likely to be realized when $\mathrm{Accel}^{\circledR}$ or BA is applied at 10- to 15$\mathrm{mm}$ KFD and results in significant cropload reduction.

Although NAA + carbaryl was assessed only in 1995 and 1996, this combination was remarkably consistent across fruit development stages in producing good fruit weight and reducing cropload, except that application of NAA+ carbaryl at 15-mm KFD in 1996 thinned somewhat excessively (Table 3). Although CAFW was significantly greater for Accel ${ }^{\circledR}$ than for NAA + carbaryl when applied at 15-mm KFD each year, application of NAA + carbaryl significantly increased CAFW when applied from PF to 10-mm KFD in 1995 and from PF to 5-mm KFD in 1996. NAA + carbaryl also resulted in a higher CAFW than

Table 1. Effects of timing of Accel ${ }^{\circledast}$ application $\left(75 \mathrm{mg} \cdot \mathrm{L}^{-1}\right)$ on fruit weight, crop load, and return bloom of 'Empire' apple trees on M.9/MM.111rootstock (Highland, N.Y., 1994).

\begin{tabular}{lccccc}
\hline \hline $\begin{array}{l}\text { Application } \\
\text { time }\end{array}$ & $\begin{array}{c}\text { Crop load } \\
(\text { fruit/cm }\end{array} \mathrm{cmCSA}^{\mathrm{y}} \mathrm{TC}$ & $\begin{array}{c}\mathrm{Wt} / \text { fruit } \\
(\mathrm{g})\end{array}$ & $\begin{array}{c}\text { Cropload adjusted } \\
\text { fruit wt. (CAFW) }\end{array}$ & $\begin{array}{c}\text { Seed no. } \\
\text { per fruit }\end{array}$ & $\begin{array}{c}\text { Return bloom } \\
(\%)\end{array}$ \\
\hline Control & $11.0 \mathrm{a}^{\mathrm{x}}$ & $113 \mathrm{~d}$ & $127 \mathrm{~b}$ & $6.9 \mathrm{ab}$ & $30.6 \mathrm{c}$ \\
Full bloom & $8.6 \mathrm{bc}$ & $134 \mathrm{bc}$ & $133 \mathrm{ab}$ & $7.2 \mathrm{ab}$ & $50.4 \mathrm{~b}$ \\
Petal fall & $7.9 \mathrm{c}$ & $135 \mathrm{bc}$ & $130 \mathrm{ab}$ & $7.3 \mathrm{a}$ & $43.8 \mathrm{bc}$ \\
5-mm KFD & $7.2 \mathrm{c}$ & $141 \mathrm{ab}$ & $132 \mathrm{ab}$ & $7.3 \mathrm{a}$ & $57.1 \mathrm{ab}$ \\
$10-\mathrm{mm}$ KFD & $7.6 \mathrm{c}$ & $148 \mathrm{a}$ & $141 \mathrm{a}$ & $6.7 \mathrm{~b}$ & $69.0 \mathrm{a}$ \\
15-mm KFD & $9.7 \mathrm{ab}$ & $124 \mathrm{~cd}$ & $131 \mathrm{ab}$ & $4.5 \mathrm{c}$ & $52.7 \mathrm{ab}$ \\
LSD $_{0.05}$ & 1.7 & 12 & 12 & 0.6 & 16.4 \\
\hline
\end{tabular}

${ }^{2}$ Full bloom is $80 \%$ of flowers open; petal fall is the time when almost all petals have just fallen from trees; remaining designations indicate mean king fruit diameter (KFD).

${ }^{y} \mathrm{TCSA}=$ trunk cross-sectional area.

${ }^{x}$ Mean separation by Waller-Duncan's LSD at $P \leq 0.05$ did Accel ${ }^{\circledR}$ when applied at PF and 5-mm in 1995 and at 5-mm 1996. These observations suggest that NAA + carbaryl does not compromise fruit weight when applied at PF to 5-mm KFD. Earlier reports indicated improved CAFW when NAA was applied at bloom or petal fall vs. 10-mm KFD (Robinson and Lakso, 1991).

Why NAA + carbaryl increases CAFW is unknown. Much of this effect may be explained by reduction in fruitlet competition by earlier fruitlet abscission and greater thinning to single fruits per spur. Application of NAA + carbaryl resulted in significantly more spurs with single fruit spurs than did every comparable Accel $^{\circledR}$ or Accel $^{\circledR}+$ carbaryl treatment in 1996; averaging $16.6 \%$ more spurs with a single fruit. In the one year when NAA and Accel $^{\circledR}$ were each combined with carbaryl, the NAA combination significantly increased percentage of spurs bearing a single fruit by $12 \%$.

Normal weather variability may compromise field studies comparing thinner effectiveness at different fruit development stages. Examination of temperatures throughout the thinning period (Fig. 1) indicates that maximum daily temperatures were much higher on days when some treatments were applied, and that cooling trends followed application of some treatments. However, these weather conditions did not appear to markedly change plant response. For example, despite the very high temperatures following PF treatments in 1996 (Fig. 1C), no PF application significantly reduced cropload (Table 3). Also, 10mm KFD treatments resulted in substantial thinning in both 1994 (Table 1) and 1996 (Table 3 ), even though daily maximum temperatures were somewhat cool during the few days after application (Fig. $1 \mathrm{~A}$ and C). These results suggest that thinner effectiveness is influenced more by phenological stage and associated physiological processes than by moderate differences in temperature.

Our results show that the combination of NAA or Accel ${ }^{\circledR}$ with carbaryl was more effective in thinning 'Empire' apple than was NAA or $A_{c c e l}{ }^{\circledR}$ alone, which agrees with earlier reports (Forshey, 1986; Greene and Autio,

Table 2. Effects of chemical treatment and timing on fruit weight, crop load, and return bloom of 'Empire' apple trees on M.9/MM.111 rootstock (Clintondale, New York 1995).

\begin{tabular}{|c|c|c|c|c|c|c|c|c|}
\hline Treatment $^{\mathrm{z}}$ & $\begin{array}{c}\text { Application } \\
\text { time }^{y}\end{array}$ & $\begin{array}{c}\text { Crop load } \\
\text { (fruit/cm } \mathrm{cm}^{2} \mathrm{TSA}^{\mathrm{x}} \text { ) }\end{array}$ & $\begin{array}{c}\text { Spurs with } \\
\text { single fruit }(\%)\end{array}$ & $\begin{array}{c}\text { Wt/fruit } \\
(\mathrm{g})\end{array}$ & $\begin{array}{l}\text { Cropload adjusted } \\
\text { fruit wt (CAFW) }\end{array}$ & $\begin{array}{c}\text { Red fruit color } \\
(\%)\end{array}$ & $\begin{array}{l}\text { Seed no. } \\
\text { per fruit }\end{array}$ & $\begin{array}{c}\text { Return bloom } \\
(\%)\end{array}$ \\
\hline Control & & $16.9 \mathrm{a}^{\mathrm{w}}$ & $72.4 \mathrm{~g}$ & $96 \mathrm{f}$ & $117 \mathrm{f}$ & $67.5 \mathrm{~d}-\mathrm{g}$ & $6.4 \mathrm{ab}$ & $7.1 \mathrm{~d}-\mathrm{f}$ \\
\hline \multirow[t]{4}{*}{ NAA+carbaryl } & Petal fall & $9.5 \mathrm{e}$ & $87.3 \mathrm{a}-\mathrm{d}$ & $145 \mathrm{ab}$ & $131 \mathrm{bc}$ & $73.6 \mathrm{a}-\mathrm{d}$ & $6.0 \mathrm{a}-\mathrm{c}$ & $18.2 \mathrm{bc}$ \\
\hline & 5-mm KFD & $10.1 \mathrm{de}$ & $91.1 \mathrm{a}$ & $141 \mathrm{bc}$ & $130 \mathrm{~b}-\mathrm{d}$ & $78.0 \mathrm{a}$ & $5.9 \mathrm{a}-\mathrm{c}$ & $20.0 \mathrm{bc}$ \\
\hline & 10-mm KFD & $9.5 \mathrm{e}$ & $87.6 \mathrm{a}-\mathrm{c}$ & $142 \mathrm{bc}$ & $127 \mathrm{~b}-\mathrm{e}$ & $75.1 \mathrm{a}-\mathrm{c}$ & $5.8 \mathrm{bc}$ & $62.2 \mathrm{a}$ \\
\hline & 15-mm KFD & 8.9 e & $90.4 \mathrm{ab}$ & $137 \mathrm{~cd}$ & $120 \mathrm{e}-\mathrm{f}$ & $77.0 \mathrm{ab}$ & $5.9 \mathrm{a}-\mathrm{c}$ & $56.5 \mathrm{a}$ \\
\hline \multirow[t]{4}{*}{ Accel $^{\circledR}$} & Petal fall & $15.2 \mathrm{ab}$ & $79.0 \mathrm{~d}-\mathrm{g}$ & $109 \mathrm{e}$ & $122 \mathrm{~d}-\mathrm{f}$ & $68.9 \mathrm{c}-\mathrm{f}$ & $5.8 \mathrm{a}-\mathrm{c}$ & 3.1 ef \\
\hline & 5-mm KFD & $16.7 \mathrm{a}$ & $71.4 \mathrm{~g}$ & 101 ef & 121 ef & $70.2 \mathrm{~b}-\mathrm{e}$ & $5.8 \mathrm{a}-\mathrm{c}$ & $4.9 \mathrm{~d}-\mathrm{f}$ \\
\hline & 10-mm KFD & $13.3 \mathrm{bc}$ & $82.0 \mathrm{c}-\mathrm{f}$ & $128 \mathrm{~d}$ & $132 \mathrm{bc}$ & $66.3 \mathrm{e}-\mathrm{g}$ & $5.8 \mathrm{a}-\mathrm{c}$ & $13.5 \mathrm{bd}$ \\
\hline & 15-mm KFD & $12.3 \mathrm{c}$ & $82.6 \mathrm{~b}-\mathrm{e}$ & $133 \mathrm{~cd}$ & $132 \mathrm{~b}$ & $65.8 \mathrm{e}-\mathrm{g}$ & $5.5 \mathrm{c}$ & $11.2 \mathrm{c}-\mathrm{e}$ \\
\hline \multirow[t]{3}{*}{ BA-3138 } & Petal fall & $15.9 \mathrm{a}$ & $73.8 \mathrm{f}-\mathrm{g}$ & $108 \mathrm{e}$ & $124 \mathrm{c}-\mathrm{f}$ & $62.3 \mathrm{fg}$ & $6.1 \mathrm{a}-\mathrm{c}$ & $1.8 \mathrm{f}$ \\
\hline & 10-mm KFD & $9.8 \mathrm{e}$ & $75.3 \mathrm{e}-\mathrm{g}$ & $153 \mathrm{a}$ & $141 \mathrm{a}$ & $72.1 \mathrm{a}-\mathrm{e}$ & $6.1 \mathrm{a}-\mathrm{c}$ & $21.2 \mathrm{~b}$ \\
\hline & 15-mm KFD & $11.7 \mathrm{~cd}$ & $84.0 \mathrm{a}-\mathrm{d}$ & $137 \mathrm{bc}$ & $134 a b$ & $61.1 \mathrm{~g}$ & $6.6 \mathrm{a}$ & 3.8 ef \\
\hline $\mathrm{LSD}_{0.05}$ & & 1.9 & 8.4 & 9 & 8 & 6.9 & 0.8 & 9.1 \\
\hline
\end{tabular}

${ }^{2} \mathrm{NAA}$ used at $7.5 \mathrm{mg} \cdot \mathrm{L}^{-1}$; carbaryl at $600 \mathrm{mg} \cdot \mathrm{L}^{-1} ;$ Accel $^{\oplus}$ and BA-3138 at $75 \mathrm{mg} \cdot \mathrm{L}^{-1} \mathrm{BA}$.

${ }^{y}$ Full bloom is $80 \%$ of flowers open; petal fall is the time when almost all petals have just fallen from trees; remaining designations indicate mean king fruit diameter (KFD).

${ }^{\mathrm{x}} \mathrm{TCSA}=$ trunk cross-sectional area

wMean separation by Waller-Duncan's LSD at $P \leq 0.05$. 
Table 3. Effects of chemical treatment and timing on fruit weight, crop load, and return bloom of 'Empire' apple trees on M.9/MM.111rootstock (Clintondale, N.Y., 1996).

\begin{tabular}{|c|c|c|c|c|c|c|c|c|}
\hline Treatment $^{2}$ & $\begin{array}{l}\text { Application } \\
\text { time }^{y}\end{array}$ & $\begin{array}{c}\text { Crop load } \\
\left.\text { (fruit } / \mathrm{cm}^{2} \mathrm{TCSA}^{\mathrm{x}}\right)\end{array}$ & $\begin{array}{c}\text { Spurs with } \\
\text { single fruit }(\%)\end{array}$ & $\begin{array}{c}\text { Wt/fruit } \\
(\mathrm{g})\end{array}$ & $\begin{array}{l}\text { Cropload adjusted } \\
\text { fruit wt. (CAFW) }\end{array}$ & $\begin{array}{l}\text { Seed no. } \\
\text { per fruit }\end{array}$ & $\begin{array}{c}\text { Fruit } \\
\text { L/D ratio }\end{array}$ & $\begin{array}{c}\text { Return bloom } \\
(\%)\end{array}$ \\
\hline Control & & $9.0 \mathrm{a}^{\mathrm{w}}$ & $52.5 \mathrm{~h}$ & $150.6 \mathrm{f}$ & $159.9 \mathrm{fg}$ & $4.6 \mathrm{ab}$ & $0.85 \mathrm{~d}$ & $86.1 \mathrm{e}$ \\
\hline \multirow[t]{4}{*}{ NAA } & Petal fall & $7.8 \mathrm{a}-\mathrm{d}$ & $75.9 \mathrm{a}-\mathrm{c}$ & $158.4 \mathrm{~d}-\mathrm{f}$ & $160.9 \mathrm{e}-\mathrm{g}$ & $4.0 \mathrm{~b}-\mathrm{d}$ & $0.87 \mathrm{a}-\mathrm{d}$ & $86.7 \mathrm{e}$ \\
\hline & 5-mm KFD & $7.1 \mathrm{~b}-\mathrm{g}$ & $70.4 \mathrm{~b}-\mathrm{d}$ & $160.6 \mathrm{~d}-\mathrm{f}$ & $159.2 \mathrm{~g}$ & $4.2 \mathrm{~b}-\mathrm{d}$ & $0.86 \mathrm{~cd}$ & $90.3 \mathrm{~b}-\mathrm{e}$ \\
\hline & 10-mm KFD & $7.9 \mathrm{a}-\mathrm{d}$ & $68.6 \mathrm{c}-\mathrm{e}$ & $162.4 \mathrm{c}-\mathrm{f}$ & $165.6 \mathrm{~b}-\mathrm{g}$ & $4.1 \mathrm{~b}-\mathrm{d}$ & $0.89 \mathrm{a}-\mathrm{c}$ & $93.1 \mathrm{a}-\mathrm{d}$ \\
\hline & 15-mm KFD & $7.6 \mathrm{a}-\mathrm{e}$ & $63.1 \mathrm{~d}-\mathrm{f}$ & $170.0 \mathrm{a}-\mathrm{d}$ & $171.5 \mathrm{a}-\mathrm{f}$ & $5.1 \mathrm{a}$ & $0.87 \mathrm{a}-\mathrm{d}$ & $91.6 \mathrm{a}-\mathrm{e}$ \\
\hline \multirow[t]{4}{*}{ NAA + carbaryl } & Petal fall & $7.5 \mathrm{a}-\mathrm{f}$ & $70.3 \mathrm{~b}-\mathrm{d}$ & $171.3 \mathrm{a}-\mathrm{d}$ & $172.3 \mathrm{a}-\mathrm{e}$ & $4.1 \mathrm{~b}-\mathrm{d}$ & $0.86 \mathrm{~b}-\mathrm{d}$ & $86.8 \mathrm{de}$ \\
\hline & 5-mm KFD & $6.1 \mathrm{e}-\mathrm{h}$ & $75.5 \mathrm{a}-\mathrm{c}$ & $179.3 \mathrm{a}$ & $172.2 \mathrm{a}-\mathrm{e}$ & $4.2 \mathrm{~b}-\mathrm{d}$ & $0.88 \mathrm{a}-\mathrm{d}$ & $93.5 \mathrm{a}-\mathrm{c}$ \\
\hline & 10-mm KFD & $5.9 \mathrm{gh}$ & $79.1 \mathrm{a}$ & $170.5 \mathrm{a}-\mathrm{d}$ & $162.4 \mathrm{c}-\mathrm{g}$ & $4.0 \mathrm{~b}-\mathrm{d}$ & $0.88 \mathrm{a}-\mathrm{d}$ & $94.2 \mathrm{a}-\mathrm{c}$ \\
\hline & 15-mm KFD & $4.7 \mathrm{~h}$ & $80.7 \mathrm{a}$ & $175.0 \mathrm{a}-\mathrm{c}$ & $159.6 \mathrm{~g}$ & $4.4 \mathrm{a}-\mathrm{c}$ & $0.89 \mathrm{a}-\mathrm{c}$ & $97.0 \mathrm{a}$ \\
\hline \multirow[t]{4}{*}{ Accel $^{\circledR}$} & Petal fall & $8.9 \mathrm{a}$ & $58.8 \mathrm{f}-\mathrm{h}$ & $153.1 \mathrm{ef}$ & $162.1 \mathrm{c}-\mathrm{g}$ & $4.2 \mathrm{~b}-\mathrm{d}$ & $0.89 \mathrm{ab}$ & $91.5 \mathrm{a}-\mathrm{e}$ \\
\hline & 5-mm KFD & $8.6 \mathrm{ab}$ & $53.7 \mathrm{gh}$ & $151.4 \mathrm{f}$ & $158.3 \mathrm{~g}$ & $4.2 \mathrm{~b}-\mathrm{d}$ & $0.86 \mathrm{~cd}$ & $89.4 \mathrm{c}-\mathrm{e}$ \\
\hline & 10-mm KFD & $7.3 \mathrm{~b}-\mathrm{g}$ & $65.1 \mathrm{~d}-\mathrm{f}$ & $161.7 \mathrm{~d}-\mathrm{f}$ & $161.4 \mathrm{~d}-\mathrm{g}$ & $4.0 \mathrm{~b}-\mathrm{d}$ & $0.90 \mathrm{a}$ & $91.7 \mathrm{a}-\mathrm{e}$ \\
\hline & 15-mm KFD & $8.0 \mathrm{a}-\mathrm{d}$ & $57.6 \mathrm{f}-\mathrm{h}$ & $175.5 \mathrm{ab}$ & $179.2 \mathrm{a}^{\circ}$ & $3.7 \mathrm{c}-\mathrm{d}$ & $0.87 \mathrm{a}-\mathrm{d}$ & $92.3 \mathrm{a}-\mathrm{e}$ \\
\hline \multirow[t]{5}{*}{ Accel $^{\circledR}+$ carbaryl } & Petal fall & $8.1 \mathrm{a}-\mathrm{c}$ & $60.9 \mathrm{e}-\mathrm{g}$ & $161.5 \mathrm{~d}-\mathrm{f}$ & $166.0 \mathrm{~b}-\mathrm{g}$ & $4.6 \mathrm{ab}$ & $0.89 \mathrm{ab}$ & $90.5 \mathrm{~b}-\mathrm{e}$ \\
\hline & 5-mm KFD & $7.7 \mathrm{a}-\mathrm{d}$ & $64.1 \mathrm{~d}-\mathrm{f}$ & $170.7 \mathrm{a}-\mathrm{d}$ & $172.8 \mathrm{a}-\mathrm{d}$ & $4.6 \mathrm{ab}$ & $0.90 \mathrm{a}$ & $92.0 \mathrm{a}-\mathrm{e}$ \\
\hline & 10-mm KFD & $6.5 \mathrm{~d}-\mathrm{g}$ & $70.6 \mathrm{~b}-\mathrm{d}$ & $180.8 \mathrm{a}$ & $175.9 \mathrm{ab}$ & $3.7 \mathrm{c}-\mathrm{d}$ & $0.89 \mathrm{ab}$ & $96.9 \mathrm{a}$ \\
\hline & 15-mm KFD & $7.0 \mathrm{c}-\mathrm{g}$ & 61.9 ef & $180.6 \mathrm{a}$ & $178.5 \mathrm{a}$ & $3.4 \mathrm{~d}$ & $0.89 \mathrm{ab}$ & $95.7 \mathrm{a}-\mathrm{c}$ \\
\hline & $\mathrm{LSD}_{0.05}$ & 1.6 & 7.9 & 12.9 & 11.8 & 0.8 & 0.03 & 6.4 \\
\hline
\end{tabular}

${ }^{2}$ NAA used at $7.5 \mathrm{mg} \cdot \mathrm{L}^{-1}$; carbaryl at $600 \mathrm{mg} \cdot \mathrm{L}^{-1}$; Accel ${ }^{\circledR}$ and BA-3138 at $75 \mathrm{mg} \cdot \mathrm{L}^{-1} \mathrm{BA}$.

${ }^{\mathrm{y}} \mathrm{Full}$ bloom is $80 \%$ of flowers open; petal fall is the time when almost all petals have just fallen from trees; remaining designations indicate mean king fruit diameter (KFD).

${ }^{\mathrm{x}} \mathrm{TCSA}=$ trunk cross-sectional area

wMean separation by Waller-Duncan's LSD at $P \leq 0.05$.

1989; Rogers and Thompson, 1983). However, when compared at all treatment timings, using a contrast analysis $(P=0.0003)$, NAA or $\mathrm{NAA}+$ carbaryl reduced cropload $12 \%$ more than did Accel $^{\circledR}$ or Accel ${ }^{\circledR}+$ carbaryl whereas in most earlier studies BA alone was more effective than NAA (Elfving and Cline, 1993; Greene and Autio, 1994). The discrepancy between our results and those reported by Elfving and Cline (1993) and Greene and Autio (1994) might be explained by their use of higher rates of BA and a BA-only formulation. In our study, larger CAFW was achieved with a BA-only treatment than with NAA + carbaryl at 10-mm KFD in 1995, although the NAA + carbaryl treatment resulted in better thinning, greater fruit weight and similar CAFW compared to Accel $^{\circledR}$ at the same timing (Table 2).

Elfving and Cline (1993) reported that BA increased return bloom of 'Empire' apple more than did NAA in one of two comparisons, whereas we found that the application of NAA + carbaryl resulted in consistently higher return bloom than did $\mathrm{Accel}^{\circledR}$ or BA at all times of application in 1995 (Table 2), and return bloom was similar for NAA + carbaryl and Accel $^{\circledR}$ + carbaryl in 1996 (Table 3). Return bloom following application of NAA + carbaryl in 1995 varied with time of treatment despite similar croploads (Table 2). The percentage of spurs with single fruit also was not consistently associated with return bloom in 1995 (Table 2). These results indicate that the influence of NAA + carbaryl on return bloom was not directly related to cropload reduction.

While most thinning trials have indicated that return bloom is largely correlated with cropload (Williams and Edgerton, 1981) and sometimes seeds $/ \mathrm{cm}^{2}$ TCSA (Greene and Autio, 1994), numerous other reports indicate that other factors may sometimes influence return bloom. Several early studies showed a marked promotion of bloom in apple trees sprayed with
NAA, even though nonthinned trees had similarcroploads (Batjer and Thomson, 1961; Harley et al., 1958; McKee and Forshey, 1966; Thompson, 1957). Thompson (1957) and Harley et al. (1958) suggested that post-bloom sprays of NAA directly stimulated the initiation of flower buds, and some apple growers continue to apply low rates of NAA to enhance return bloom of trees that do not need thinning (Unrath, personal communication). Our 1995 trial provides evidence of this effect, since comparisons of 10-mm KFD applications indicate much lower return bloom following application of BA than of NAA + carbaryl despite similar croploads. It is especially interesting that timing of NAA + carbaryl application had a large effect on return bloom, with the later treatments being more effective, even though all timings of this combination produced similar croploads. For example, cropload following NAA + carbaryl at both PF and 10-mm KFD was 9.5 fruit $/ \mathrm{cm}^{2} \mathrm{TCA}$, but the later treatment resulted in three-fold more flowering in the following spring (Table 2).

The mechanism by which NAA + carbaryl stimulates return bloom is not understood, but there is evidence which may implicate NAAeffects on photosynthate or GA distribution. Reduction of metabolite supply (reducing sugars) to young fruit has been proposed as the cause for increased fruitlet abscission when thinning with NAA (Schneider and Lasheen, 1973), and foliar application of NAA can reduce net $\mathrm{CO}_{2}$ assimilation of apple leaves (Stopar et al., 1997). Transient reduction in assimilation may reduce shoot growth as a competing sink for photosynthate, permitting more allocation of resources to flower initiation. Alternatively, the well-documented effects of NAA application on shoot flagging and reduced fruit growth, especially when applied around 10-mm KFD (Luckwill, 1953; Schneider and Lasheen, 1973) may be associated with a reduction in GA production and / or transport from seeds and shoot tips to spurs. Inhibition of apple flowering by GA application in the period following bloom is wellestablished (Greene, 1989; Marino and Greene, 1981), and Ebert and Bangerth (1981) reported that chemical thinning sprays inhibited GA diffusion from the fruits 2 weeks after bloom, and that heavy return bloom occurred on these trees.

Chemical thinners are usually applied at $\approx 10$-mm KFD in the eastern United States to permit adjustment of thinning according to initial fruit set. However, the importance of good fruit size without excessive crop reduction, and the frequent occurrence of poor thinning weather during early fruit development, suggest that apple producers should consider earlier thinning of cultivars such as 'Empire' that are prone to overproduce. Our data indicated that NAA + carbaryl at PF to 5-mm KFD significantly reduced cropload, enhanced fruit weight, and provided high CAFW comparable to the best Accel ${ }^{\circledR}$ treatment, and also generally resulted in more spurs with a single fruit than was realized with Accel $^{\circledR}$. In the 2 years of our study, these early NAA + carbaryl treatments did not overthin, and growers might consider a second thinning application of Accel ${ }^{\circledR}$ or Accel ${ }^{\circledast}+$ carbaryl at 10-mm KFD if additional thinning appears warranted. Experiments assessing this strategy have been completed and are reported in a forthcoming paper (Stover et al., 2001).

\section{Literature Cited}

Batjer, L.P. and B.J. Thomson. 1961. Effect of 1naphthyl $N$-methylcarbamate (Sevin) on thinning apples. Proc. Amer. Soc. Hort. Sci. 77:1-8.

Ebert, A. and F. Bangerth. 1981. Relationship between the concentration of diffusible and extractable gibberellin-like substances and the alternatebearing behavior in apple as affected by chemical fruit thinning. Scientia Hort. 15:45-52.

Elfving, D.C. and R.A. Cline. 1993. Benzyladenine and other chemicals for thinning 'Empire' apple 
trees. J. Amer. Soc. Hort. Sci. 118:593-598.

Forshey, C.G. 1986. Chemical fruit thinning of apples, New York Food and Life Sci. Bul. 116:1-7.

Forshey, C.G. 1990. Factors affecting 'Empire' fruit size. Proc. New York State Hort. Soc. 135:71-74.

Greene, D.W. 1989. Gibberellins $A_{4+7}$ influence fruit set, fruit quality, and return bloom of apples. J. Amer. Soc. Hort. Sci. 114:619-625

Greene, D.W. and W.R. Autio. 1989. Evaluation of benyladenine as a chemical thinner on 'McIntosh' apples. J. Amer. Soc. Hort. Sci. 114:68-73.

Greene, D.W. and W.R. Autio. 1994. Combination sprays with benzyladenine to chemically thin spur-type 'Delicious' apples. HortScience 29:887-890.

Greene, D.W., W.R. Autio, J.A Erf, and Z.Y. Mao. 1992. Mode of action of benzyladenine when used as a chemical thinner on apples. J. Amer. Soc. Hort. Sci. 117:775-779.

Greene, D.W., W.R Autio, P. Miller. 1990. Thinning activity of benzyladenine on several apple cultivars. J. Amer. Soc. Hort. Sci. 115:394-400.

Harley, C.P., H.H. Moon, and L.O. Regeimbal. 1958. Evidence that post-bloom apple thinning sprays of naphthaleneacetic acid increase blos- som bud formation. Proc. Amer. Soc. Hort. Sci. 72:52-56.

Luckwill,L.C. 1953. Studies of fruit development in relation to plant hormones. II. The effect of naphthalene acetic acid on fruit set and fruit development in apples. J. Hort. Sci. 28:25-40.

Marino, F. and D.W. Greene. 1981. Involvement of gibberellins in the biennial bearing of 'Early McIntosh' apples. J. Amer. Soc. Hort. Sci. 106:593-596.

McKee, M.W. and C.G. Forshey. 1966. Effects of chemical thinning on repeat bloom of McIntosh apple trees. Proc. Amer. Soc. Hort. Sci. 88:25-32.

Robinson, T. and A. Lakso. 1991. Thinning strategies to improve 'Empire' apple fruit size. Proc. N.Y. State Hort. Soc. 136:219-225.

Rogers, B.L. and A.H. Thompson. 1983. Effects of dilute and concentrated sprays of NAA and carbaryl in combination with daminozide and pesticides on fruit size and return bloom of 'Starkrimson Delicious' apple. HortScience 18:61-63.

Schneider, G.W. and A.M. Lasheen. 1973. Effect of NAA and Sevin on composition, development and abscission of apple fruit. HortScience 8:103104.
Stopar, M., B.L. Black and M.J. Bukovac. 1997. The effect of NAA and BA on carbon dioxide assimilation by shoot leaves of spur-type 'Delicious' and 'Empire' apple trees. J. Amer. Soc. Hort. Sci. 122:837-840.

Stover E. 1996. Optimizing crop value through chemical thinning of apple. New York Fruit Quart. 4:10-14.

Stover, E.W., M.F. Fargione, R. Risio, and X.E. Yang. 2001. Multi-step thinning of 'Empire' apple provides greater cropload reduction and fruit size. HortScience (In Press).

Thompson, A.H. 1957. Six years' experiments on chemical thinning of apples. Maryland Agr. Exp. Sta. Bul. A-88.

Westwood, M.N. 1967. Cell size, cell number, and fruit density of apples as related to fruit size, position in cluster, and thinning method. Proc. Amer. Soc. Hort. Sci. 91:51-62.

Williams, M.W. and L.J. Edgerton. 1981. Fruit thinning of apples and pears with chemicals. Agr. Info. Bul. 289.

Wismer, P.T., J.T.A. Proctor, and D.C. Elfving. 1995. Benzyladenine affects cell division and cell size during apple fruit thinning. J. Amer. Soc. Hort. Sci. 120:802-807. 